Péter Pavletits

\title{
The Golden Age of Narrow-Gauge Railways in Hungary after World War II until the Transport Policy Concept of 1968, Through the Example of the Szerencs-Prügy Narrow-Gauge Railway
}

\begin{abstract}
The purpose of my study. The main target of my study was to survey the golden age of the Hungarian narrow-gauge railways from the and of WWII until the Transport Policy Concept of 1968. Beside the survey, I examined the impact of the Transport Policy Concept of 1968 on the narrow -gauge railways, especially at the Szerencs-Prügy narrow-gauge railway.

Applied methods. Literature review including the history of the Hungarian narrow-gauge railways in the time frame of World War II and 1968. We involved sources from monographies, our own data from researches of archives, especially from MÁV Archive, and local newspapers of the above mentioned period.

Outcomes. After WWII ended, notable narrow-gauge railway constructions begun, so we can call apostrophe the quarter century as the second golden age there history, however from the early 1960 's the communist regime did not sympathize with narrow-gauge railways (New Economic Mechanism in 1968). Therefore the railway system, which was more than 5000 kilometres long before, constantly began to diminish. Nowadays only $5 \%$ of the original system has left (245 kilometers) and today narrow-gauge railways - beside four lines - have only touristical funtion. Economic policy recommendations. With the implementation of the transport policy concept, $30 \%$ of the low-traffic lines and stations were closed by diverting their traffic to the road. These measures have done a lot of damage to domestic transport. The rate of closure of the sidelines was well above the level of similar measures of the European railways, but the road development did not take place to the extent planned and the loading engineering and other development measures necessary for the successful implementation of the concept were largely cancelled. The leftover railway network could not become an engine for the development of transport, its performances decreased and road transport took over the tasks of the railways even in areas where the railway proved to be more uneconomic.
\end{abstract}

Keywords: narrow-gauge railways, Three-year Plan, First Five-year Plan, Transport Policy Concept, Szerencs

\section{The narrow-gauge railways after World War II}

The World War II caused much more serious damages to the Hungarian narrow-gauge railway network than the World War I. The tracks were destroyed for a significant length , most of the vehicles were taken abroad, and larger artefacts were blown up. ${ }^{1}$ The front lines also swept away the last remnants of feudalism, the aristocracy fled, the huge count's estates and faiths were left without their owners. This also affected the narow-gauge railways serving the estates, with insignificant traffic, stolen by the former maidens and the surrounding population, they began to perish. The population was not attached to the narrow-gauge railway, as it had not served its interests before. ${ }^{2}$

The Provisional National Government, formed in the last months of the war, announced its land reform program on March 17, 1945. During the reform, the narrow-gauge railways belonging to the large estates were also removed from the possession of the old owners, and

Fodor, I. (2013): 12.

Nagy, T. (2019): 15. 
according to Soviet practice, they were simply taken away from the owners without redemption, compensation or consideration.

According to the government's idea at the time, the narrow-gauge railways would be taken over by the agricultural cooperatives and they would take care of their operation. However, most of the railways were damaged to such an extent by the events of WWII, that the cooperatives were only able to put them into operation to a limited extent even after the explosives were found, so this solution did not seem economically appropriate. Although the land reform and the initial cooperative life kept some of the railways alive, they ran only for local freight on the strength of the new owners. Basically, these narrow-gauge railways were built to transport the crop from the farmlands of the large estate to the connecting MÁV (Hungarian State Railways) station and to the main points of animal husbandry, the majors. In many cases, they did not even affect settlements, these lines were closed fastest. ${ }^{3}$ Nevertheless, the importance of the remaining narrow-gauge railways has been appreciated for economic and political reasons, bringing its second golden age in connection with the reconstruction of the country. Where a narrow-gauge railway was built, the operation of this relatively cheap means of transport came to the fore because of the expected - relative - fast transport, where it was not working for the fulfillment of increased state orders. ${ }^{4}$ The fact that the narrow-gauge railways were able to flourish after the World War II was due to their cheap construction and maintenance costs. ${ }^{5}$

In 1946/1947, a dispute broke out between the Ministry of Agriculture (FM) and the Ministry of Transport (KM) on the issue of narrow-gauge railways. Government Decree No. 930/1947 Gov. 930/1947 entrusted the railway operator's supervision to the Railway Department of KM, while its owner remained the Land Management Fund.

As part of the Three-year Plan announced on 1 August 1947, the Ministry of Transport (KM) has launched a decree no. 32.359/947.I/2 in the National Narrow-gauge Railway Reconstruction Plan for narrow-gauge railways. The National Planning Office has allocated HUF $54 \mathrm{M}$ for the reconstruction of the railways, of which $2700 \mathrm{~km}$ of track renovation, the replacement of rolling stock and the construction of $255 \mathrm{~km}$ of tracks are foreseen. ${ }^{6}$ In the ministerial call, the ministry instructed the MÁV departmental engineers to organise temporary transport councils on their territory. These temporary transport councils were tasked with drawing up the reconstruction plan. The members of the Commission were the heads of the County Headquarters of the State Building Office, the MÁV Departmental Engineering at the seat of the legislative authority, the County Land Registry, the farmers' cooperatives and the National Association of New Landowners (UFOSZ). One of the main parts of the reconstruction plan was a draft plan, which included the existing solid paved road and the public rail network, the new solid paved roads included in the framework of the Three-year Plan, and the narrow-gauge railway network existing on 1 January 1944. Another main part is a questionnaire asking for an assessment of the railways falling within the competence of the department engineers.

At that time, according to the position of the narrow-gauge railways in agricultural production, four characteristic types emerged. Portable narrow-gauge railways for the replacement of railway lines, private operating railways, larger farms and production units for transport between private operating railways, larger economies and production area units, and portable economic railways for the transport of limited public economic railways, larger economic and production units. ${ }^{7}$ In parallel, KM established the Directorate of Economic Railways (GVI) on 23 July 1947 by Decree No. 9030/1947 of the Prime Minister. The Board had a dual function: on the one

\footnotetext{
Felek, F. (2017): 1.

Majdán, J. (2014): 161.

Fodor, I. (2003): 12.

Nagy, T. (2019): 15.

Csanádi, Gy. (1954): 66.
} 
hand, to save it from destruction and to collect the old large-scale railway material, and on the other hand to manage the post-war restoration of the remaining narrow-gauge railways and the construction of new lines meeting new agricultural requirements. Mihály Lörinczy, Senior Technical Adviser, was appointed to lead the Board of Directors. The newly formed Directorate distributed a total of $5425 \mathrm{~km}$ of narrow-gauge railways in the following distribution: $2000 \mathrm{~km}$ of mining railways, $150 \mathrm{~km}$ of industrial railways, $700 \mathrm{~km}$ of forest railways, $105 \mathrm{~km}$ of railways owned by the Defence Treasury, and $2470.6 \mathrm{~km}$ of railways in agricultural service. In November 1947, the rolling stock park consisted of 64 locomotives, 32 motor cars, 4 rail cars, 28 passenger cars and 8774 freight wagons.

The GVI administration operated for more than a year, in October 1948, Minister of Transport Ernő Gerő ordered that the economic railways be managed by the Economic Railway Department of the Ministry of Transport, thus nationalising them. The economic railways were then managed by four plant management companies (Győr, Kaposvár, Szolnok, Békéscsaba). $1150 \mathrm{~km}$ was rebuilt from the $2470 \mathrm{~km}$ network of lines established on the former estates, which increased to $1720 \mathrm{~km}$ with organized network development, $1100 \mathrm{~km}$ of the network had a limited public transport character. ${ }^{8}$ Only railways with public transport were set up for passenger traffic, and since passenger transport on the economic railways was considered as an ancillary task, modern vehicles for passenger transport were not built for a long time.

The transport task of the economic railways was defined in two directions: it mainly transported agricultural crops to the railway transshipment and processing plants, but they also played an increasing role in serving the larger construction sites. ${ }^{9}$

On 14 January 1949, the Ministry of Transport requested the Council of Ministers to establish National Economic Railway Companies (GVNV) for reconstruction and operation of economic railways. The proposal was submitted by the Government on 21 January 1949 in the $9 / 1949$ MT. A total of 34 lines (557.2 km in length), $371.1 \mathrm{~km}$ of lines to be restored in the future, $408.5 \mathrm{~km}$ to be restored but not covered by credit, $561.8 \mathrm{~km}$ of sugar factories and other lines, were placed under the management of GVNV. Their line length was $2302.0 \mathrm{~km} .{ }^{10}$

At the time of the establishment of the companies, Minister of Transport Lajos Bebrits carried out inspections of several narrow-gauge railway stations, in which he found, among other things, that freight rates, especially for construction materials, were overpriced, timetables were inaccurate, steam locomotives were dirty, careless, and that the working areas were rubbish. Furthermore, the transhipment of narrow-gauge railways are too far from the normal railways, so the transfer involves significant extra work, the stops are not indicated, the general work discipline is poor and there is no coordination between the narrow-gauge railways. ${ }^{11}$

Each national company is designed as follows:

- National Company of The Economic Railways of Győr, headed by Gyula Horváth,

- National Company of Economic Railways of Kaposvár, headed by István Mandl,

-National Company of Economic Railways of Székesfehérvár, headed by Sándor Károlyi

- National Company of Economic Railways of Szolnok, headed by János Jónás,

- National Company of Economic Railways in Mezőhegyes, headed by András Kristóf,

- National Company of Economic Railways in Gyula, headed by János Ballagó,

- National Company of Economic Railways in Szerencs, headed by István Tóth.

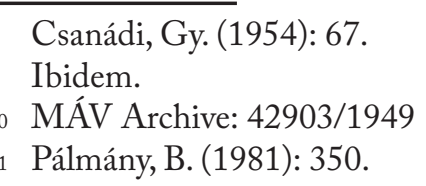


The forest railways have been placed under the supervision of the Hungarian State Forestry Plants (MÁLLERD), the industrial railways and mining railways serving the factories and factories under the supervision of the Ministry of Industry. ${ }^{12}$

In 1949, the Central Leadership of the Hungarian Workers' Party stated that the Threeyear Plan was a plan for reconstruction, recovery of the Hungarian economy affected by war damage and destruction. ${ }^{13}$ At that time the „battle” between road and rail was still winning by rail, narrow-gauge railways received greater central support instead of developing poor-quality dirt roads. This has brought with it the renovation of existing transport networks and the construction of new lines, while the need for production or procurement of narrow-gauge diesel locomotives has also been put on the agenda to meet the increased traffic needs. The Threeyear Plan was to build 136 towing vehicles, mostly diesel engines, on the 68 lines to be opened. On a two hundred and forty-kilometer run, a new economic railway line was established, and nine hundred and fifty kilometers the tracks were restored. In the first year of planning, the construction of the new lines of Tápiószentmárton - Sövegpuszta $(7.6 \mathrm{~km})$, Pusztaföldvár (5.6 km), Szeghalom - Töviskés (12 km), Gyopáros - Rákóczitelep (3 km), Inám - Somogyszil (6 $\mathrm{km})$, Harangod - Megyasszó (11 km), Kisújújhely - Csorba (12 km), Nyírlugas - Nyírbéltek (9.5 $\mathrm{km}$ ) and Szentes-rural was envisaged. After the World War II, a 12-kilometer long railway line was built as first in the country, in the Viharsarok, between Tótkomlós and Békéssámson, which was inaugurated by Ernő Gerő himself. The illustrious event was reported by the MAFIRT Chronicle No. 107 in February 1948.

In the imagination of the planners, a sewerage network spanning the country was also visualized, which, in addition to relieving transport problems by water, would have even solved the task of irrigation. ${ }^{14}$

On 15 January 1949, by decree No. 450/1949 of the Government, the economic railways were taken over by the Treasury. The Communist leadership, which came to power this year, nationalized every company with more than 10 employees. Hungarian sugar factories were also included in this, which handed over their network of narrow-gauge railways outside the factory gate to the seven GVNVs. That's when the real work started: narrow-gauge railway lines were rebuyed and new settlements were extended to the country's circulation. Some examples: from $600 \mathrm{~mm}$ to $760 \mathrm{~mm}$, the Tarnaszentmiklós - Hatrongyos-puszta line was rebuilt and extended to Pély, or the Szerencs GV, which was $700 \mathrm{~mm}$ from the range of sugar factories, was also breached to the standard $760 \mathrm{~mm}$. In addition to extending and extending existing lines, a significant number of lines were given the resolution instead of renovated due to either their condition or expected traffic. ${ }^{15}$

The First Five-year Plan, published on 1 January 1949, one of the most important objectives was to mechanise agriculture. Mechanization increased the precise, scheduled internal transport of the large agricultural plant, made agriculture more productive, reduced the proportion of heavy physical work, and also reduced the difference between the village and the town. ${ }^{16}$

The dieselization programme of the related Ministry of Metallurgy and Machinery has already defined the supply of modern fleets of vehicles to the lines. The main objective was to optimise the use of energy in railways, since diesel towing vehicles installed instead of steam locomotives used approximately one-fifth energy than steam locomotives to carry out traction tasks. ${ }^{17}$

Malatinszky, Cs. (2009): 90.

Balogh, S. - Izsák, L.- Mészáros, K. (1976): 203.

14 Szikszai, M. (2017): 190.

Felek, F. (2017): 2.

Csanádi, Gy. (1954): 67.

Czére. B. (1962): 4. 
On 31 December 1949, the seven GVNVs were reorganized, their number decreased to five, Szerencs was attached to Szolnok, Székesfehérvár was attached to Győr, and Mezőhegyes and Gyula were merged under the name Békéscsabai GVNV. In addition, from the next day, a national repair department was organized under the name of Economic Railways Repair Service National Company, which was responsible for the repair and reconstruction of rolling materials by national economic railway companies. ${ }^{18}$

The beginning of the decade brought new line extensions and the construction of new lines. The propaganda machine started, and the tapes were cut more than once by Lajos Bebrits himself, minister of transport. The optimistic atmosphere of the period was also captured by the vernacular, such as „Bebrits loader truncated” and „Kadocsa detour”. In 1952, the production of two of the three iconic vehicles of the narrow-gauge railraways, the C50 type diesel engine locomotive manufactured by the MÁV Northern Vehicle Repairer and the GV Bak passenger cars manufactured by the MÁV Debrecen Vehicle Repairer began. The third icon is the R lowry, which has become the largest number of vehicles on Hungarian narrow-gauge railways, the origin of which dates back to the Monarchy. In Ozd and Diósgyőr it was possible to roll rails again for the narrow-gauge railways, and in the tracks built from 1951, these steel rails were weighing 12 and 14 kilograms per running metre. ${ }^{19}$

Optimism did not last long, and by the second half of 1952, forced growth had plunged Hungary into the biggest transport crisis of all time, exacerbated by the lack of coal. With this precedent, the dieselisation of the economic railway network, estimated to be almost $2500 \mathrm{~km}$ long, began. ${ }^{20}$

In addition to the development of economic operation, the main priority of the First Fiveyear Plan was the development of passenger traffic. However, their existence was due precisely to the fact that the area they led to was not adequately equipped with means of transport. The possibility has given itself the opportunity to start regular, scheduled passenger transport where there is a need. Such a need is to reach the main railway, the administrative centre, go to school or work, market, visit a hospital, doctor or church. ${ }^{21}$ According to the GV Traffic and Signalling Instructions valid from 1 May 1954, regular traffic has already been recorded on 43 lines of 27 narrow-gauge railway stations.

The first more serious fact-finding study of the economic railways after the World War II carried out in January 1955. The 1st Railway Department of the Ministry of Transport and Postal Affairs (KPM) ordered a revision investigation of the economic railways. ${ }^{22}$ The investigation revealed serious accounting deficiencies and disorganizations, which were partly due to frequent staff changes and partly due to missing qualifications. As a result of the investigation, the inadequate or unqualified cadres with workers with accounting skills was replaced. Those who had accounting skills without railway qualifications were obliged to provide professional education.

In 1951, the first scientific institution dealing with railways, the Institute for Railway Science Research was founded, which dealt with, among other things, the technical and economic issues of economic railways. The irony is that ten years later, the Institute was beaten the first angle to the coffin of the economic railways. ${ }^{23}$ The studies at the time discussed the optimal sharing of transport tasks between transport sectors and the operational and economic issues of economic railways. The institute was also the last refuge for class alien elements removed from the railways.

18 Pálmány, B. (1981): 354.

19 Felek, F. (2017): 2.

20 Pavletits, P. (2014): 57.

21 Pavletits, P. (2017): 50.

22 MÁV Archive: 99/1955.

23 Czére, B. (1962): 3. 
Another reorganization soon came: István Kossa Minister of Transport and Post 107.264/1960.I.3. As of 31 March 1960, the Directorate of Economic Railways (GVI) was abolished by the merged into the organization of the Hungarian State Railways. The next day, 1 April 1960, the 44 operating departments with a line length of $1223 \mathrm{~km}$ were subordinated to the six railway directorates of MÁV, their name changed to MÁV Economic Railways (MÁV $\mathrm{GV}) .^{24}$

With the handover, the period of terminations began. ${ }^{25}$ The merger did not bring about any major changes in the day-to-day work of the economic railways, the MÁV only exercised the control and the main management rights. The control and management of the traffic and commercial work of the economic railway chiefs was carried out by The Directorate's Division III. A timetable was drawn up for the audit, in which the three-month verification had to be ensured. It was then that the driving system of the economic railways was also transferred to the competence of MÁV.

The loss of the importance of the narrow-gauge railways was already apparent, the GV cost plan managed by the Directorate for Material Supply and The General Accountant on planning and accounting issues followed the gardening cost plan.

\section{Picture 1: Unadulterated economic railway sentiment in Somogyszil in 1954}

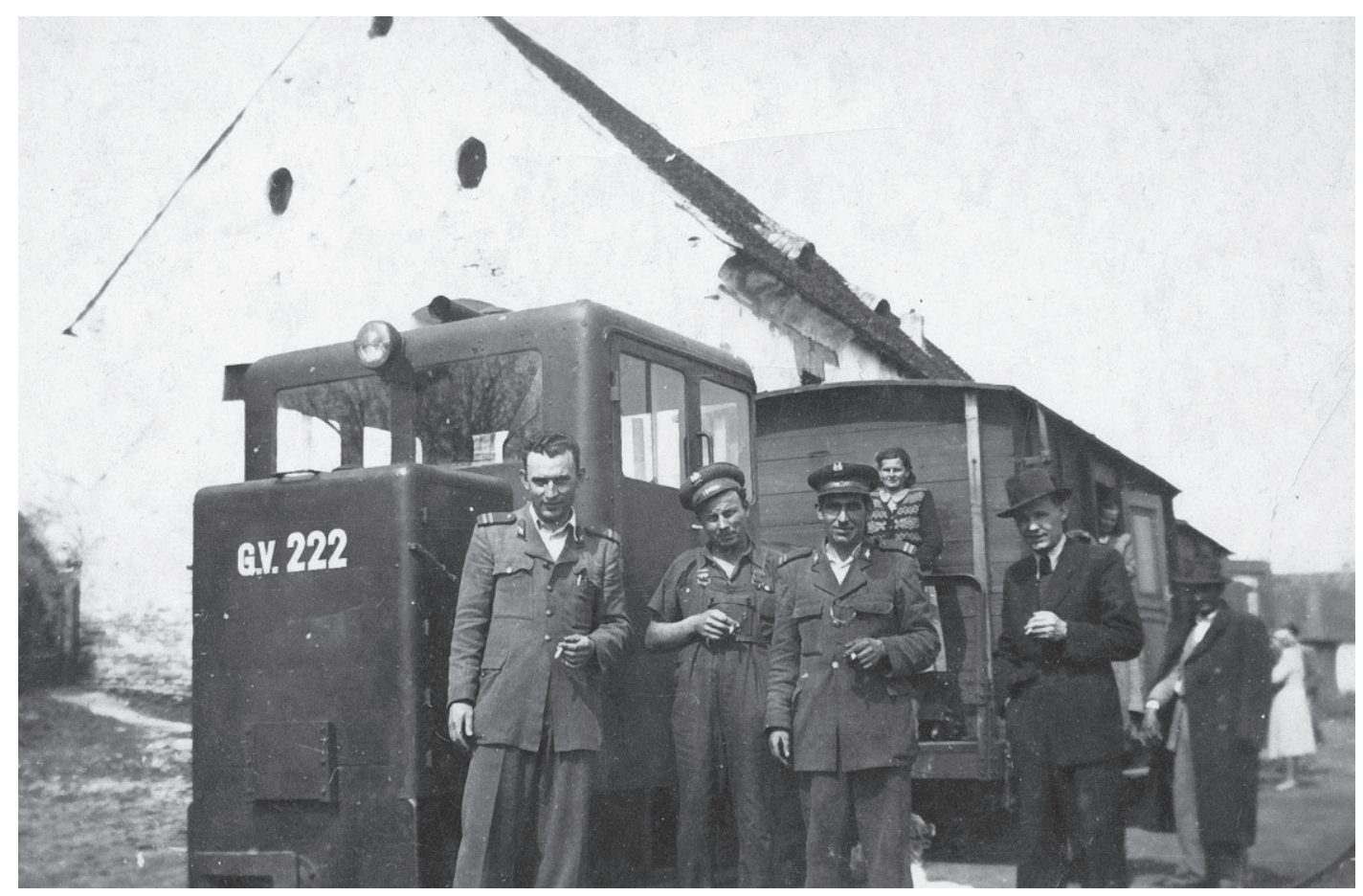

Source: Fortepan/Erky-Nagy Tibor

In the 1960's, Hungary transport policy was changed, there were not enough resources for the simultaneous construction and development of railways and roads, and therefore an election situation emerged. ${ }^{26}$ While at the beginning of the period they sought to bring the mosaic-like network together, after 1956 the collection of tracks and the directing of traffic to the road began at a rapid pace. ${ }^{27}$ It shows that during the post-war restorations, not thorough reconstruction, but in many cases, as with the normal-gauge railway, there was extension-patching in the absence of money and materials, as well as maintenance. In particular, expensive and slow duct work was

24 MÁV Archive: 5415/1960.

25 Felek, F. (2013): 3.

26 Tóbiás,L. (1996): 14.

27 Majdán, J. (2014): 161. 
missed, which sooner or later sealed the fate of the superstructure. At this time, two thirds of the network is outdated and in poor condition, which significantly reduced the speed of track, which caused the increase in rail transport. Within a few years, the replacement of the tracks and relays was virtually discontinued, the maintenance of the track was limited to sporadic undergrowth, repair of already traffic-prone track faults, scrubbing and snow shoveling.

In 1962, based on the use of the data from 1961, the staff of the Railway Scientific Research Institute, the Scientific Research Institute for Motor Transport and the Institute of Road Sciences carried out a study entitled „Detailed exploration of limited narrow-gauge railway lines in the operation of MÁV with regard to traffic, the technical condition of the line and the possibilities of road transport". ${ }^{28}$

In the mid-1960s, the total length of the narrow-gauge railway network reached $4000 \mathrm{~km}$, which was roughly half the length of the normal track gauge network, but their freight traffic was disproportionately smaller, with only $3 \%$ of the total volume of goods being transported. This already suggested that the operation of the majority of narrow-gauge railways could not be economical. ${ }^{29}$ The other main problem was the seasonality, with moderate freight and passenger traffic in the network for three quarters of the year, but in the autumn months the narrow-gauge railways performed $75 \%$ of the total annual traffic on the limit of their performance.

The test material also showed that over the next ten years MÁV would have to spend a total of HUF 318 million on track renovation on thirty GV lines. ${ }^{30}$ The partial dismantling of the railway lines was already under way, and the railway directorates had dismantled the disused sections of track in their territory.

On 1 January 1968, the new economic rail tariff came into force, which resulted in the revenue of the economic railways for freight almost entirely being foregone due to the higher tariffs laid down for the lines.

In May 1968 KPM had categorized the economic railways in its survey in four different categories:

Group 1: Loss-making lines, traffic to be diverted to the road

Group 2: Loss-making lines, their traffic cannot be diverted to a road

Group 3: Profitable lines, traffic can be diverted to the road

Group 4: Profitable lines, their traffic cannot be diverted to a road. ${ }^{31}$

Regardless of whether the individual economic railways were operating with profit, it should be noted that the profits were made at a significant price supplement in each unit, or were operating at a loss, it proposes to close the railway everywhere. Untrue costs were often included in the economic calculations, thus justifying its uneconomic nature. As a justification, it cites either an existing road running in parallel or under planning, adjusting the planned date for the closure of the line according to the existence of the road or the planned construction. Interestingly, the biggest loss was at the operation of the Economic Railways of Mezóhegyes. The rail connected the settlements around Mezőhegyes (Árpádhalom, Végegyháza, Mezőkovácsháza, Kunágota, Kevermes, Lőkösháza, Dombiratos, Dombegyháza, Battonya) and the sixty-five majors of the State Farm of Mezôhegyes in a length of 172 kilometers. Due to the lack and outdated roads, the most problematic thing here was the road distribution.

On 5 September 1968, the government discussed and in October 1968 Dr. György Csanádi, Minister of Transport and Post, presented to the Parliament the new Transport Policy Concept (1024/1968 (X. 31.), which was adopted by the Parliament, which made the destruction of narrow-gauge railways and normal track gauges legal, which had been going on for nearly

28 Balogh, I. (2010): 21.

29 Czére, B. (1994): 39.

30 Felek, F. (2017): 9.

31 MÁV Archive: 10049/1970. 
a decade. ${ }^{32}$ The herding of traffic of loss-making and low-traffic railways to public roads has begun. $^{33}$

According to the basic concept, the people's economy did not require transport tasks to be fulfilled from specific sectors, but from transport as a whole. To this end, road freight transport has been liberalised and transport districts have been abolished. The aim is to increase the share of road transport, for which the related government decision ordered the dismantling of the economic railways. In the end, the development of the concept was best motivated by the introduction of a new economic management system. The new economic mechanism also imposed requirements on the management of transport development. ${ }^{34}$

Attempts were made to keep some lines alive, they organized their transfer from the MÁV to other organizations. This is how, among other things, the discontinuing Kaposvári GV became used by the Somogyjád Constitution Agricultural Cooperative, ${ }^{35}$ the railway line between Balatonfenyves - Táska and Balatonfenyves - Somogyszentpál was managed by the Balaton Nagyberek State Farm, but the local cooperative also led the Bácsalmás and Csorvás GV plants. The wing line of the Tarnaszentmiklós GV Hatrongyos-puszta - Pély was to be handed over to the Kiskörei State Farm in order to solve the problem of transporting the farm schoolchildren to school. ${ }^{36}$ In Sárszentmihály, thanks to the lime sludge mine, GV was in operation until 1992.

On 14 January 1969, a timetable for the winding-up of the economic railways was published, which included 31 December 1980 as the final date for the dismantling of the entire network. In a few weeks' time, on 4 February 1969, the above target date was amended by the end of 1975 . As a result, the performance of the narrow-gauge railways still in operation has continued to decline. In parallel with the reduction of GV lines the sale or transfer of C50 type locomotives to forest and industrial railways had been started. ${ }^{37} \mathrm{It}$ is a telling fact that in 1971 the production of the Hungarian narrow-gauge railways concrete sleeper was also stopped.

The decision did not address the oil price, and at the time of its creation - in the mid-1960s - it did not matter at all in the Western or Eastern bloc. Statistics from pre-line economic surveys have often been designed to favor the road.

In addition to the issue of job opportunities for former workers, it was also a problem that they were able to travel for free or at a very affordable price, so the KPM's General Directorate of Railways ordered that students and former railway workers be reimbursed for a price difference between bus and rail transport for three years. ${ }^{38}$

The closure and transfer of the sidelines did not result in any significant savings, the financial situation of MÁV deteriorated further. One of the unspoken aims of the concept has become the solution of the increasingly problematic railway labor situation. Since the 1970s, labor shortages have been a serious problem - it is not for nothing that insurance equipment developments and the large-time engineering of track maintenance work have started with great force. There was also a severe shortage of staff on track maintenance - which is why they tried to transfer staff from already low-traffic railway lines to major, busier service stations. At the same time, the closure of low-traffic railway lines is not a Hungarian specialty, a process that has already taken place in Western European countries. (In Britain, it was shut down because it turned out that the concept was flawed. Here, the line closure law was famous as Beeching

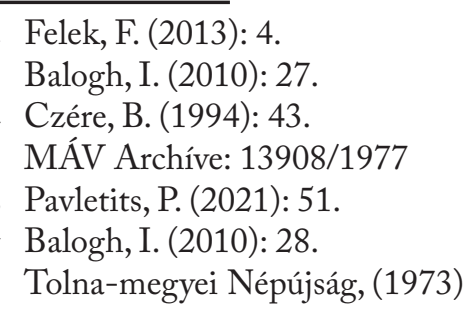


Axe.) However, the other socialist countries did not follow suit. The freight transport functions of small railways have increasingly been replaced by the tourist function. ${ }^{39}$

\section{Impact of the Transport Policy Concept of 1968 on the narrow -gauge railways}

With the transport policy concept, the Hungarian government sealed not only the fate of the economic railways, but also the sideline network of the whole country. From the above tables it can be seen that the government has given a good ten years to eliminate traffic on 1200 kilometers of narrow-gauge economic railway lines and divert them entirely to the road. The same thing takes place as in the early 1900s, when, in adverse, poor traffic conditions, carts and horse-drawn carriages were difficult or unable to meet the demands at all, but vice versa, now they have decided not to develop the railway, but to wither it. With the development of motorization and the poor condition of narrow-gauge economic railways in some places, the track has not been renovated everywhere, so road vehicles have been able to meet the needs better. ${ }^{40}$

With the implementation of the transport policy concept, $30 \%$ of the Hungarian low-traffic lines and stations were charged, and their traffic was replaced to a lesser part by the district of loading - dispatch and delivery of goods - and, to a large part, by diverting their traffic to the road. Those with a traffic density not exceeding 400 freight ton $\mathrm{km} / \mathrm{km} /$ day and 200 freight tons $/ \mathrm{km} /$ day of narrow-gauge lines were considered to be low-traffic railway lines. ${ }^{41}$

These measures have done a lot of damage to domestic transport. The rate of closure of the sidelines was well above the level of similar measures of the European railways, but the road development did not take place to the extent planned and the loading engineering and other development measures necessary for the successful implementation of the concept were largely cancelled. The economic basis for implementing transport policy was intended by the transport government to cover the result of the savings from the shift, which was not established. The railway network, deprived of its sidelines, could not become an engine for the development of transport, its performances decreased and road transport took over the tasks of the railways even in areas where the railway proved to be more uneconomic. ${ }^{42}$

Of course, well-functioning lines remained in economic rail transport, but the next three decades until the change of regime were determined by the Concept. Regardless of the fact that the main objective was to dismantle the railway lines, improvements were also made. In 1969 a new section was handed over on the Nyírvidék narrow-gauge Railway, and the railway line running in the interior of Nyíregyháza was relocated outside of the city. ${ }^{43}$

\section{The schematic history of the Szerencs-Prügy narrow-gauge railway}

The town of Szerencs is one of the district centers of Borsod-Abaúj-Zemplén county, at the southern foot of the Zemplén Mountains, surrounded by highway nr. 37 and the Hatvan Miskolc - Szerencs - Sátoraljaújhely main railway line. The settlement has been inhabited since prehistoric times, according to Anonymus chronicle, Grand Prince Árpád of the Magyars camped with his leaders on the way from Hung Castle in the field next to the Takta stream. From the $15^{\text {th }}$ century it was Rákóczi and then Andrássy estate. From 1874, Andrássy trust, the estate around Szerencs with the centre of Parno (now Slovakia) count Manó Andrássy has become a trustee.

\footnotetext{
39 Csapó, J. - Huszti, Zs. (2011): 3.

40 Csáki, J. (1965): 10

41 Frisnyák, Zs. (2012): 102.

42 Horváth, F. (1996): 60.

43 Villányi, Gy. (1990): 371.
} 
Already in 1848, the Pest - Miskolc- Kassa - Galicia direction was designated as one of the six national main lines, but in the years of the war of independence this was not built. The first locomotive entered the Miskolc station in the spring of 1859. However, on a significantly modified route, Szolnok - Debrecen - Nyíregyháza took a detour to reach Miskolc. With this, Miskolc and the entire northeastern region were disadvantaged, since the distance with Pest was not shortened, but doubled. As a result of this bypass, Szerencs and Tokaj in Zemplén were put in a favorable position for a while, which could have caused serious transit traffic, so Szerencs became a truly prosperous settlement. ${ }^{44}$

In 1888, the superiors of Zemplén County asked the government to support the establishment of a sugar factory because of the grape phylloxera and the underdeveloped industry in the area. In 1889, the largest sugar factory and refinery in Europe was built in Szerencs.

Two decades later, Szerencs was recognized that the most efficient way to approach the crop factory is by rail, most economically by narrow-gauge railway. At the request of The Hungarian Sugar Industry Co., the Minister of Trade ordered the administrative access of the narrow-track steam-powered economic railway to Balhás-tanya, on the outskirts of the village of Taktaszada from Szerencs, on 4 February 1911. ${ }^{45}$ With this, the construction of the economic railway network in the Szerencs area, which was later 85 kilometers long, began.

The biggest challenge of the construction of the railway was the crossing of the Miskolc - Szerencs main railway line at the track level, the approval of which took many years to start construction. The cross-level crossing and related facilities were built by the royal state railways at the expense of the sugar factory. Finally, the factory was granted permission to use the crossroads only for the current marketing year, according to decree no. 266744/1917 of the Hungarian Royal Railways Directorate dated 9 August 1917, so that the crossing, barriers and safety devices were dismantled by the railway after 30 April 1918 at the expense of the factory. The sugar factory, of course, asked for the level cross to be perpetuated, at which point it was still unsuccessful.

After the Treaty of Peace which ended the World War I, the country's sugar demand decreased. Due to the expensiveness of sugar, capacity underutilization occurred due to low consumption, and production of the factory fell by a third. This was counterbalanced by largescale improvements. ${ }^{46}$ Part of this, among other measures - in 1923 the sugar factory was supplemented by cocoa and chocolate factory - is also the development of the narrow-gauge railway. On 10 October 1920, the Management of the Hungarian Sugar Industry Co. Szerencs Factory and the Zemplén Agricultural Limited Company applied for the construction of a 700-millimeter horse towing economic railway from the yard of the factory to the steam mill, which was approved by the Administrative Committee of the County of Zemplén under the heading "Turncuted Hungary is not a country, whole Hungary is a heaven” on 8 March 1921. The line was visited by art police on 13 July of the current year.

In 1926, the line was extended to the count Sándor Szirmay's rental farm. The official check was held on 7 September 1926 by the Hungarian Royal Inspectorate of Railways and Shipping, and on 23 June 1928 it was converted from a horse plant to an engine-powered one by decree of the Inspectorate of General.

In the 1930's, Szerencs's industry and agriculture developed steadily. It is interesting in the history of railways that one of the main advocates of the raison d'être of narrow-gauge railways, Endre Sármezey, retired ACsEV railway director, author of several professional volumes, argues in his essay entitled „Comment on the question of the construction of economic railways” in the

44 Dienes, D. (2013): 116

45 Vasúti és Közlekedési Közlöny (1911)

46 Figyelő (1986) 
15 November 1930 issue of the Hungarian national newspaper, arguing for the correctness of his principle with a positive example of the Szerencs narrow-gauge railway.

Progress was broken by World War II. In 1944, major war damage also hit the area around Szerencs, and the military units that marched through robbed the granaries, took away supplies and livestock. At the beginning of 1945, after the front had gone, the sugar beet crop was collected for the restart of the sugar factory, and the maids were put to free public work. The owners of the estate, but also the farmers, fled, leaving only lower leaders in place. The maids made their apartments habitable, took possession of the land, and during the land division they requested land around the farmsteads with the help of land-claiming and allocating committees. The land reform was decided by Government Decree No. 600/945, and the question of ownership of railways was decided by Government Decree No. 450/949. First, state farms were formed in the farm centers, e.g. The State Economy of Harangod, Szerencs, Takta interstate. Individual enterprises continued to be connected by economic railways. ${ }^{47}$ At the national congress of the Hungarian Workers' Party held on 12 June 1948, the delegation from Szerencs proposed the initiation of passenger and freight traffic, and in September 1948, ${ }^{48}$ at the request of the municipality of Prügy, a limited public traffic was authorized by Ernő Gerő, Minister of Transport. The lines of the south have been partially modified.

In 1949 István Tóth was appointed director of the National Company of Szerencs Economic Railways. At that time, there were twenty-eight narrow-gauge railway lines to Szerencs. A year later, four of the seven national companies were merged, and Szerencs came under Szolnok control.

As a result of the first 5 year economic plan, the main line of the southern network remaining in operation, the main line of Szerencs-Prügy and the Dohányos wing line were segmented from 700 millimeters to 760 millimeters in the first half of 1952. The Tiszamenti Water Works Company recommended help for the crossing. In August 1949, the Tiszaluc Agricultural Distillery National Company requested a similar crossing correction on the 3-kilometer stretch between Tiszalúc and Gabriella-tanya, but this was not realized at the time due to a lack of resources. But the spirits factory promised to generate a lot of traffic. ${ }^{49}$

The socialist labor competition did not miss Szerencs either, the first place in the stahanovist loader category in 1952 was won by Béla Éliás loader with an average performance of 164.2\% in six months. The third place finisher is also from Szerencs, Albert Bártfai had an average performance of 163.3\%. József Dóri, supervisor of Szerencs, became the best of the sugar mill production workers. ${ }^{50}$ In 1954, the Szolnok workshop renovated the two passenger cars of the narrow-gauge railway with record speed. ${ }^{51}$

47 Högye, I. (2001): 562.

48 Zempléni Népújság (1948)

49 MÁV Archive: 38748/1949

50 Cukoripar (1952)

51 Észak-Magyarország (1954) 


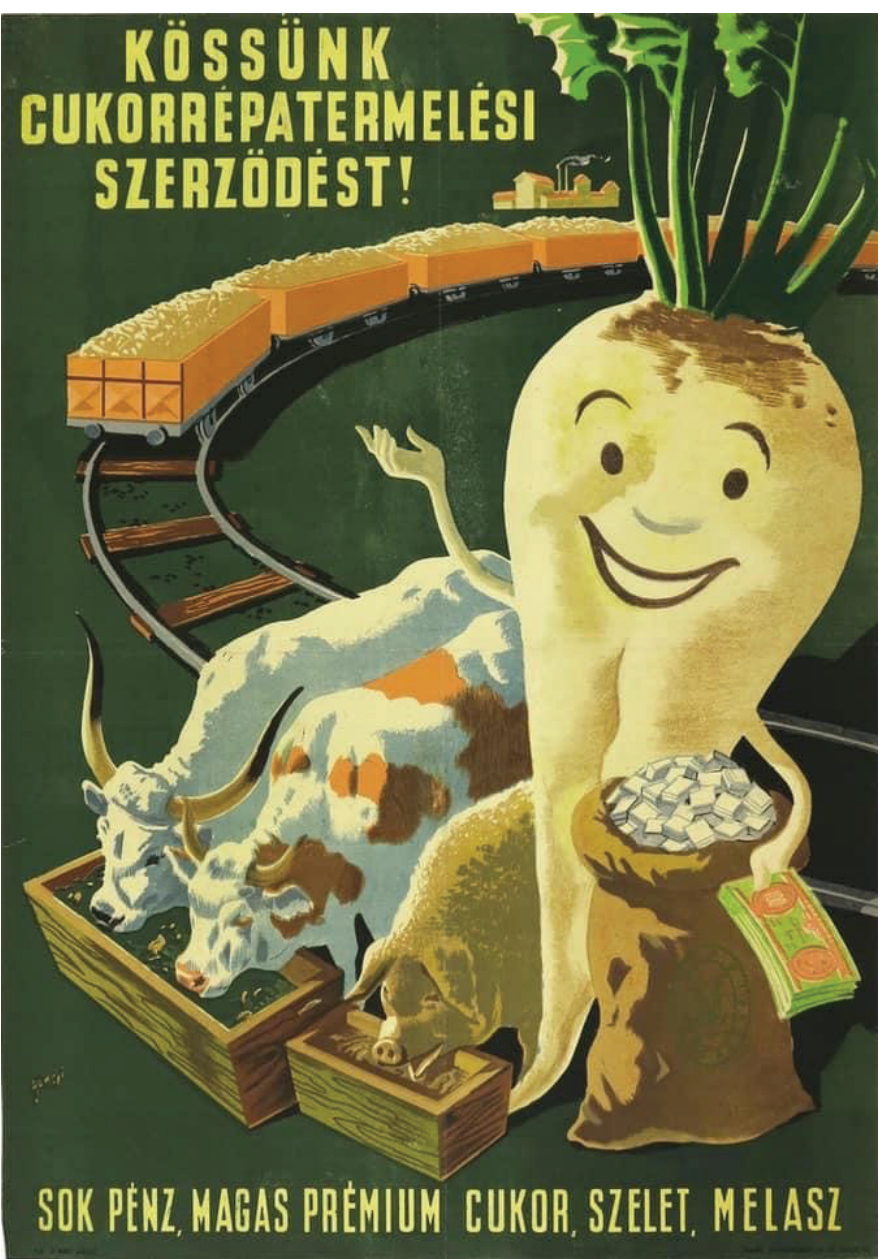

Picture 2: Let us make a crop contract for sugar-beet! A great many, high quality sugar, sugar beet slice, molasses. The propaganda poster from the author's collection, in the atmosphere of the 1950s. Who could resist those calling words? Of course, the reality is not always so wonderful: Imre Rajháti, the chief anarchist of the Balatonfenyves State Farm, who, by the way, is one of Rákosi's minions, embezzled the premium due to farmers interested in sugar beet production. After his capture, he didn't even stop for South America.

The operation of the railway was taken over by the Directorate of Economic Railways of the KPM on 1 January 1955. As part of the 1956 renovation programme, UVATERV was prepared as part of the 1956 renovation programme of the KPM I. Railway Department under the number 7159/1/ U-6 under the title "Study of narrowgauge railway renovations in the vicinity of Szerencs". After receipt, the line was renovated and upgraded with tracks weighing $14 \mathrm{~kg} / \mathrm{m}$, as the entire line was previously built with rails weighing $7 \mathrm{~kg} / \mathrm{m}$. The $7 \mathrm{~kg} / \mathrm{m}$ rails remained exclusively on the Cseger-delta - Dohányos-tanya wing line. Between Szerencs and Prügy, both the person and the freight transport were carried out entirely on the economic railway, since the two localities and the farmsteads between them were not connected by road. In addition, on the network, the beet transports of the Szerencs Sugar Factory - about 1500 wagons of sugar beet, 1000 wagons of beet bars - were also carried out by the railway, which handled some of the external and internal deliveries of the sugar factory's target economy.

The five-year GVI era was followed by MÁV management from 1 April 1960. On 22 November of the following year, the MÁV Miskolc Directorate carried out a comprehensive investigation. The investigation concluded, inter alia, that one of the three wagons with a half-framed passenger car is dangerous for accidents, is not suitable for passenger transport, and that the capacity of the remaining two carriages is not sufficient to carry out increased traffic, often over 100 people. Another shortcoming is that there is no waiting room at either Szerencs or Prügy terminus, there is drinking water only at Szerencs main station and the staff of the train arriving at the last Prügy daily were sleeping in the car in the absence of a sleeping area (barracks). At that time, the railway was promised to receive two four-axle carriages from the Gyula narrow-gauge railway, which ceased to exist in January 1962. The missing waiting room was taken care by the Executive Committee of the Municipal Council of Prügy before the winter came. ${ }^{52}$ Soon, the freight and passenger fleet became more modern. The previously used 2.5-ton lowries were replaced by MÁV 5-ton trucks. At this time, $4 \mathrm{Mk} 29$ series diesel locomotives (motorised (M) narrow-gauge $(\mathrm{k})$ on the basis of the track number system as amended on 1 August 1957, C50

52 MÁV Archive 17179/1961 
locomotives), 5 Bak passenger cars and 10 G., 50 I and Ia. 5-5 ton freight wagon was available for the railway. It has an annual passenger turnover of 156,764 people and a turnover of 61,408 tons.

The main line started at the factory station in Szerencs, in the southwestern part of the sugar factory area. The end station consisted of a two-way siding, from which a spur led to the stall. The approximately $500 \mathrm{~m}$ long track in the extension of the siding led to the sugar factory weighing track and from there to the inner loading track with a turntable. Before the final siding, a track about 600 meters long from the trunk line approached the warehouse building of MÁV Szerencs station, to which it joined in two places. Leaving the station, the trunk line passed parallel to the Miskolc-Sátoraljaújhely MÁV line, then crossed the then two-track MÁV line by crossing the runway without breaking the track. The trains often waited hours for a permit to cross the normal gauge railway, making regular transport completely impossible. It is interesting that in September 1956 UVATERV planned an overpass to replace it, which unfortunately did not materialize, as it promised to be uneconomic from both an operational and investment point of view. After the track crossing came the junction to Malom-tanya $(8.1 \mathrm{~km})$. The trunk line then turned away at Kocsonthát, then along the Prügy vineyard road it moved southwards. At section 41, a junction was built to Rosszmalom-tanya $(400 \mathrm{~m})$, then at section 28 it reached the watercourse of the Takta-canal, which it crossed with a larger bridge. After the bridge expired, the mohos-pusztai connecting track branched out. In section 74, another junction was built for the Miklós-tanya $(1.4 \mathrm{~km})$, then at section 81 towards Nagycseger-puszta - Szabóhomok $(7.2 \mathrm{~km})$. This branch served the cattle fattening plant of the Borsod-Abaúj-Zemplén County Animal Dealer Company. Another branch was built for Urrét-major (section 90, $1.7 \mathrm{~km}$ in length) and then in section 103 for the lower loader for public relations. The main line was completed next to the Taktaharkány - Tokaj driveway in the village of Prügy with a two-track end-of-line siding. The total length of the track network was 32.1 kilometers. The lines have been fully adapted to the agricultural boarding, therefore the directional conditions are very unfavorable.

The above mentioned draft proposed the modernisation of the main line. It was then that the extension of the main line arose in the length of Prügy - Hodostanya - Báj - Csobaj - Tiszatardos - Tiszaladány - Tokaj 25 kilometers, Prügy - Taktakenes - Tiszadada-rév 8 kilometers and the production site of the Szerencs Quarry Company about 2.5 kilometers long.

The year 1960 is an excellent year in the life of the Szerencs narrow-gauge railway: under the leadership of Tibor Szegedi, the 381,000 tons transport plan was completed to 130\%, reaching 419,000 tons, and they won the annual congress competition of the economic railways. ${ }^{53}$ In the 1960s, twenty-five people worked in the locomotive and wagon repair shop, fifteen in track maintenance (PFT) positions, one manager and four traffic controllers in the traffic department, sixteen engine drivers, and twenty-two ticketing and train attendants. There were five pairs of passenger trains a day, with beet chops, cereals, potatoes and corn making up the majority of the freight traffic, in addition to sugar beet transport.

\section{Impact of the Transport Policy Concept on the Szerencs-Prügy Narrow-gauge Railway}

Section 11 of the KPM Railway Department. After a survey in May 1968, the Trade Department classified Szerencs as a loss-making category that could not be diverted to the road. On 18 June 1968, with effect from 31 December 1972, the KPM ordered the closure of the railway in accordance with the concept's low-traffic rail programme. The Traffic Management Committee carried out the necessary territorial investigation, but despite agreeing with the

53 Észak-Magyarország 1960 
Picture 3: Typical economic railway mood in Szerencs

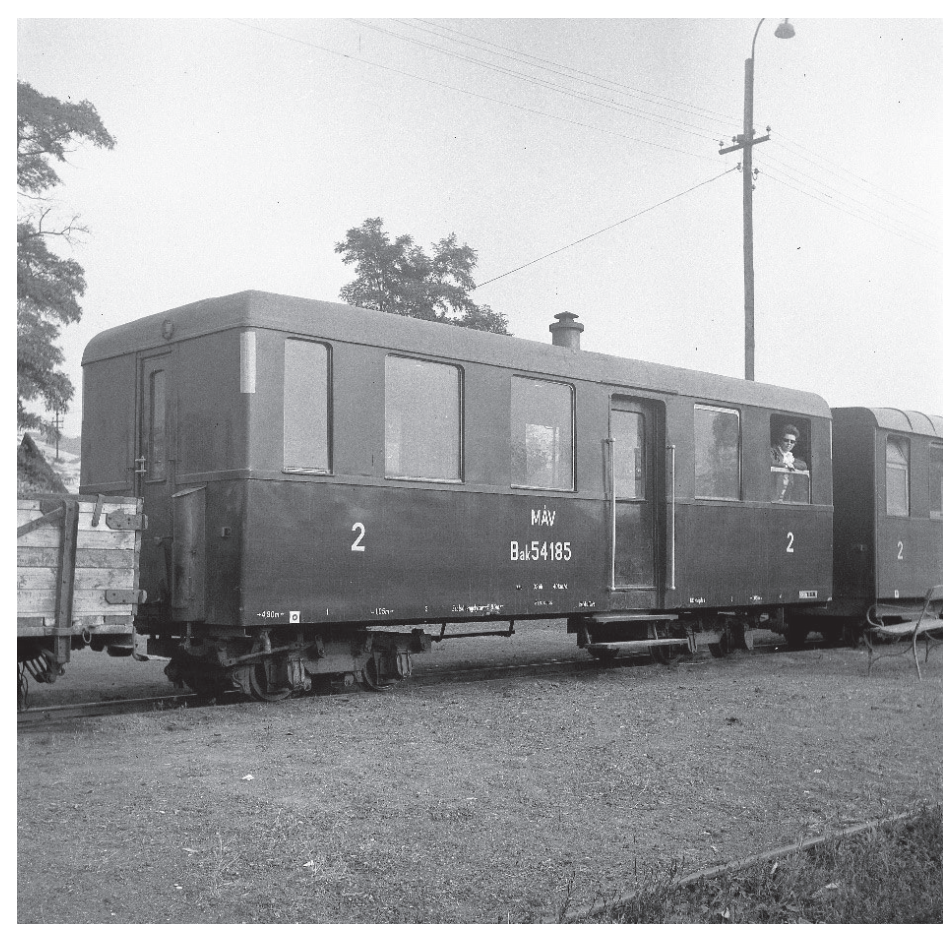

closure, it proposed a target date for the planned closure after 1975 . According to the proposal, the return on road construction investment related to the closure is more than 10 years, which is considered unfavorable. In this case, the investment amount of approximately HUF 35 million could be used for major road construction works. The condition of the track at that time satisfied the existing needs. ${ }^{54}$ The Volán Automobile Transport Trust also agreed with the shift, but made the acceptance of freight transport tasks subject to the complete completion of road construction tasks due to the extremely poor road conditions, swampy and deep soil of the affected area. ${ }^{55}$

Source: László Mohay, 2 November 1973

Table 1: Comparison of traffic to be shifted and planned traffic to the Volán Trust

\begin{tabular}{|l|l|}
\hline \multicolumn{2}{|c|}{ Traffic to be diverted in 1971 } \\
\hline passangers / year & 158500 \\
\hline workers / year & 57900 \\
\hline students / year & 18000 \\
\hline tons of goods / year & 17200 \\
\hline passanger km / year & 2350000 \\
\hline worker km / year & 853000 \\
\hline student km / year & 284000 \\
\hline tons of good km / year & 177300 \\
\hline & \\
\hline & \\
\hline passangers / year & 182100 \\
\hline workers / year & 54100 \\
\hline students / year & 6600 \\
\hline tons of goods / year & 4800 \\
\hline passanger km / year & 151030 \\
\hline worker km / year & 372000 \\
\hline student km / year & 31000 \\
\hline tons of good / year & 29400 \\
\hline
\end{tabular}

Source: MÁV Archive: 111095/1970

\footnotetext{
54 MÁV Archive $11195 / 1971$

55 MÁV Archive: 111108/1973
} 
On 30 November 1972, Dezső Kiss, Deputy Minister of the KPM, discussed in Miskolc the three railway line closures affecting the county (i.e. Pretzels, Szerencs, Bodrogköz), at which time the target date for the closure of Szerencs was set at December $1974 .{ }^{56}$ The railway finally ceased to exist later, on 7 November 1975, generating a further loss of HUF 1.5 million over three years, while road construction costs doubled in three years. The railway track was demolished on the basis of the KPM Railway Department's demolition permits no. 103397/1976.6.A. The locomotives were scrapped on December 10. For 50 million forints, a new road was built on the trail of the existing dirt road. The investment requirement for car transport is 1 bus (HUF 525,000 ), one truck (HUF 135,000). In the last year of operation, the railway carried 158,000 passengers and 17,000 tons of goods, mostly students and commuters. Of course, the railroad was buzzing, shaking, the little cars were buzzing, you had to hold on, like you were sitting on a camel's back. The Wheel will be different, in winter or in the heavy rain, schoolchildren will fall behind and without them will begin arithmetic. That's how the local press mourned the narrowgauge railway at the time.

Picture 4: The remaining tracks on the territory of the Szerencs sugar factory, with the chimney totors of the closed factory in the background

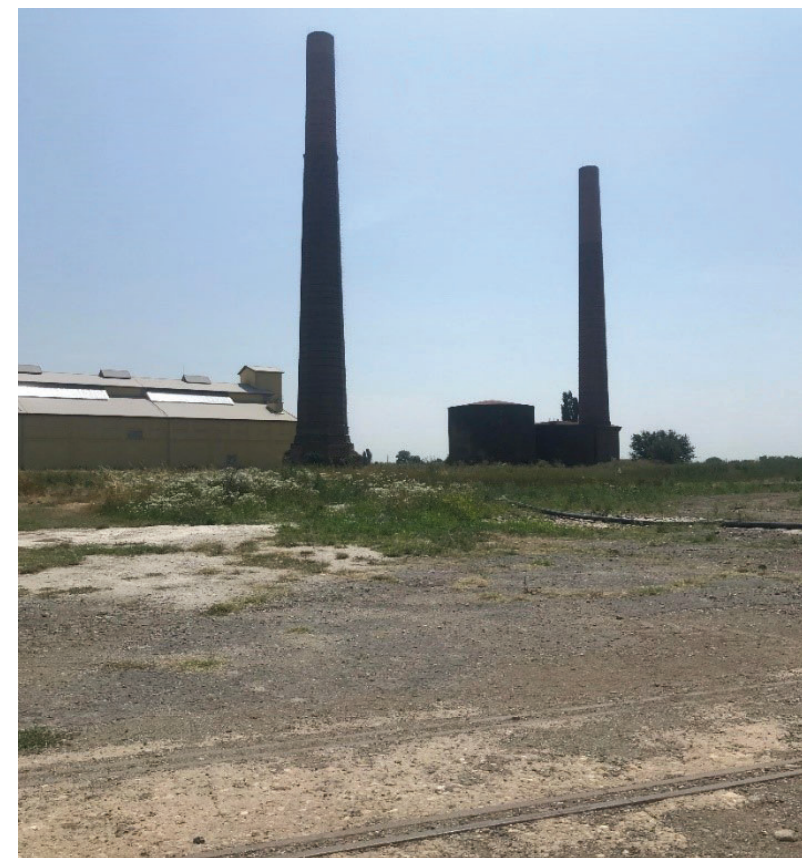

Source: Peter Pavletits on 27 July 2021
Although the autonomy of the GV plant management of Szerencs-Prügy MÁV was abolished on 1 September 1972 - when it was assigned to 5 traffic controllers and 4 train attendants - the freed-up workforce at the time of termination caused MÁV less problems than the 208 people crew of the Bodrogköz narrow-gauge railway, which was wearing similar shoes. ${ }^{57}$

On September 15, 1975, the Miskolc Road Construction Company handed over the 12-kilometer-long, 6-meter-wide road between Szerencs and Prügy. ${ }^{58}$ On April 26 1977, the Szerencs Sugar Factory also submitted a partial siding demolition request to the Hungarian State Railways. The sugar factory, already without a railway, defied the "latest economic mechanism" for another thirty years and closed on 10 March 2008. The chocolate factory became foreign-owned in 1991. That's how the glory of the sweet world passed in Szerencs. ${ }^{59}$

\section{Bibliograpy}

Balogh, I. (2010): Emlékkönyv. 60 éves a balatonfenyvesi gazdasági vasút. Balaton-Boronka Kisvasút Nonprofit Közhasznú Kft., Balatonfenyves

Balogh, S.-Izsák, L.-Mészáros, K. (1976): Magyar történeti szöveggyüjtemény I. 1944-1953. Tankönyvkiadó, Budapest

Dienes, D. (2013): A Sárospataki Református Kollégium története. Hernád, Tiszáninneni Református Kiadó, Sárospatak

56 Észak-Magyarország (1972)

57 MÁV Archive 4053/1973

58 Észak-Magyarország (1975)

59 Pavletits, P. (2020): 56 
Czére, B. (1962): Az 1961. október 23.-26. közt a MÁV Vezérigazgatóság kultúrtermében megtartott elsó tudományos ülésszak anyaga. Vasúti Tudományos Kutató Intézet, Budapest

Czére, B. (1994): Közlekedéspolitikai koncepció, 1968. In: Villányi, Gy. (Ed.): Vasúthistória Évkönyv, Budapest

Csanádi, Gy. (1954): Vasúti üzem. Tankönyvkiadó, Budapest

Csapó, J. - Huszti, Zs. (2011): Vasúti közlekedés. In: Veres, L. (Ed.): Turizmus és közlekedés, PTE, Pécs

Csáki, J. (1965): Keskeny nyomtávolságú vasútvonalak állapota. Budapest. (Author's original manuscript, MÁV Archive)

Felek, F. (2013): A Sarkadi GV története. (Author's original manuscript, use with the permission of Author)

Felek, F. (2017): Gazdasági vasutak - Születéstöl a MÁV-ig. (Author's original manuscript, use with the permission of Author)

Fodor, I. (2003): A keskeny nyomközú vasutak közlekedés földrajzi jelentösége Magyarországon. ELTE TTK, Budapest

Frisnyák, Zs. (2012): A kisforgalmú vasútvonalak bezárása a Kádár-korszakban. In: A Közlekedési Múzeum évkönyve, MMKM, Budapest

Horváth, F. (1996): A helyiérdekú vasutak épitése és üzeme Magyarországon, Vasúthistória Évkönyv, Közdok Kft., Budapest

Hőgye,I. (2001): Az Andrássy család hitbizományi birtokai és gazdálkodása 1867, 1874-1944. Agrártörténeti Szemle Vol. XLIII. (2001) No. 3-4. 539-564.

Majdán, J. (2014): A közlekedés története Magyarországon (1700-2000). Pécsi Tudománytár, Pécs

Malatinszky, S. (2009): Magyarország Gózmozdonyai. A 490-es sorozat. Magyar Államvasutak Zrt., Budapest

Nagy, J. (1994): MÁV Rt. Kecskeméti Kisvasút. Kecskemét

Nagy, T. (2019): Az adácsi lóüzemú gazdasági vasút története. Sínek világa, Budapest

Pavletits, P. (2014): Kisszériás történet. Magyar szolgálatban a keletnémetek igás Lowa. Indóház vasúti magazin, Vol. 10. No. 6. Budapest

Pavletits, P. (2017): Keskenynyomtávon a Mezóföldön. Fejezetek a lepsényi gazdasági vasút történetéból. Indóház vasúti magazin, Vol. 13. No. 3. Budapest

Pavletits, P. (2020): Kötöttpályán Kocsontahátra és a Rosszmalom-tanyáboz, fejezetek a Szerencs környéki gazdasági vasutak történetéböl. Indóház vasúti magazin, Vol. 16. No. 5. Budapest

Pavletits, P.(2021): Kötöttpályán a Tisza mentén, homokországban, Fejezetek a Tarnaszentmiklós- Hatrongyos puszta - Pély gazdasági vasút történetéból. Indóház vasúti magazin, Vol. 17. No. 1. Budapest

Pálmány, B. (1981): Dokumentumok a magyar közlekedés történetéból. Források a magyar népi demokrácia történetéhez. Új Magyar Központi Levéltár, Budapest

Szepesi, L. (1973): Megszúnik-e a dombóvár-lepsényi vasútvonal? Tolna megyei Népújság, Vol. XXIII. No. 21.

Szikszai, M. (2017): Adatok Jász-Nagykun-Szolnok megye kisvasútjainak történetéhez 1945 után. Zounuk, Magyar Nemzeti Levéltár, Jász-Nagykun-Szolnok Megyei Levéltára Évkönyve. Szolnok

Tóbiás, L. (1996): A magyarországi kisvasutak idegenforgalmi folldrajzi adottságai. Budapest

Villányi, Gy. (1990): A Nyiregyháza Vidéki Kisvasút, Vasúthistória évkönyv. KÖZDOK, Budapest

\section{Sourcebooks and Statistics Cited}

MÁV Archive, 42903/1949: A gazdasági vasutak üzemkezelésére alakitott N. V. megnevezése (1949/21.) MÁV Archive, 38748/1949: Tiszalúc-Gabriella-tanya közötti g.v. vonal helyreállitása

MÁV Archive, 99/1955: Reviziós vizsgálat a Gazdasági Vasutaknál 
MÁV Archive, 5415/1960: Végrehajtási utasitása Gazdasági Vasutaknak az Államvasutak szervezetébe való beolvasztására

MÁV Archive, 17179/1961: A Szerencs-Prügy gazdasági vasút várója Prügyön

MÁV Archive, VG.10049/1970: Gazdasági vasutak négy kategóriába sorolása

MÁV Archive, 111095/1971: Szerencs-Prügy közötti gazdasági vasút megszüntetése

MÁV Archive, 111108/1973: Szerencs-Prügy-i GV forgalomátterelésének problémái

MÁV Archive, 4053/1973: Szerencs-Prügy MÁV GV és a Nyirbodrogi Kisvasút megszúntetése miatt felszabaduló munkaeró elhelyezése

MÁV Archive, 13908/1977: Gazdasági vasutak kezelói jog átadás Somogyjád Alk. MGTSZ

\section{Press sources}

Vasúti és Közlekedési Közlöny, 22.01.1911.

Zempléni Népújság, 30. 05. 1948.

Cukoripar, 01. 06. 1952.

Észak-Magyarország, 07. 11. 1954.

Észak-Magyarország, 09. 04. 1960.

Észak-Magyarország, 01. 12. 1972.

Tolna-megyei Népújság, No. 21.1973.

Észak-Magyarország, 26. 08. 1975.

Figyelő, 14. 08. 1986. 